\title{
Effects of aeration on phenolic amine content of guajillo
}

\author{
STEVE K. WINDELS, DAVID G. HEWITT, AND T. DAVID A. FORBES
}

\begin{abstract}
At the time of this research, Windels and Hewitt were Graduate Assistant and Assistant Professor, respectively, at the Caesar Kleberg Wildlife Research Institute, MSC 218, Texas A\&M University - Kingsville, Kingsville, Tex. 78363. Windels current address is Department of Forestry, Michigan Technological University, Houghton, Mich. 49931. Forbes was associate professor at the Texas Agricultural Experiment Station, 1619 Garner Field Rd, Uvalde, Tex. 78801.
\end{abstract}

\begin{abstract}
Aeration is a common range management technique used in southern Texas and northern Mexico to reduce shrub cover and increase biomass of more palatable forages. Guajillo (Acacia berlandieri Benth.) is an important forage plant for deer and domestic livestock throughout its range in northeastern Mexico and southern Texas. It responds to top removal, such as by aeration, by producing large numbers of juvenile sprouts which can have higher total leaf nitrogen content up to 6 months after treatment. However, the concentration of phenolic amines, potentially toxic secondary plant chemicals, may also increase. We compared concentrations of tyramine and $\mathrm{N}$-methyl-phenethylamine (NMP), 2 prominent phenolic amines that can negatively affect reproduction in herbivores, between juvenile (regrowth) and mature stems of guajillo in areas that had been aerated and also between mature stems in aerated and control sites. Aeration increased NMP but not tyramine concentrations in mature stems. Juvenile stems had higher total nitrogen concentration than mature stems but also had higher amine concentrations until about 1 year after aeration. A greater percent of total nitrogen was incorporated into amines in juvenile stems (2.5-6.0\%) than mature stems $(1.8-4.2 \%)$. Amine concentrations peaked in summer and early autumn, a period when herbivores may rely heavily on browse because forbs are scarce. Our results suggest that while aeration may result in higher nitrogen concentrations in guajillo, increases in amines may limit benefits to herbivores.
\end{abstract}

Key words: Acacia berlandieri, Chihuahuan Desert, forage quality, México, nitrogen, Tyramine

Aeration is a common range management technique used in southern Texas and northern Mexico to reduce shrub cover and increase biomass of more palatable forages (Holechek et al. 1989). This technique consists of pulling large, toothed, steel drums by a tractor or bulldozer over tracts of brush, effectively chopping off most above-ground stems of low-growing shrubs. Stems that are not completely severed are typically broken or bent over and subsequently defoliated. Guajillo (Acacia berlandieri Benth.), an important forage plant for deer and domestic livestock throughout its range in northeastern Mexico and southern Texas, responds to roller-chopping (a similar tech-

\footnotetext{
This research was funded by CEMEX and the Caesar Kleberg Wildlife Research Institute. Carrie Hensarling's assistance in amine analysis is appreciated. Reviews by T. E. Fulbright and A. Ortega-Santos improved earlier versions of the manuscript. This is publication number $02-117$ of the Caesar Kleberg Wildlife Research Institute.

Manuscript accepted 4 Nov. 02.
}

\section{Resumen}

La aereación es una técnica de manejo de pastizales comúnmente usada en el sur de Texas y norte de México para reducir la cobertura de arbustos e incrementar la biomasa de especies forrajeras deseables. El "Guajillo"(Acacia berlandieri Benth.) es una planta forrajera importante para el venado y el ganado doméstico a lo largo de su rango en el noreste de México y Sur de Texas. Esta especie responde a la remoción de su parte aérea, tal como ocurre con la aereación, produciendo un gran número de rebrotes juveniles los cuales pueden tener un alto contenido de nitrógeno total en las hojas hasta 6 meses después del tratamiento. Sin embargo, la concentración de aminas fenólicas, químicos secundarios de la planta potencialmente tóxicas, también incrementa. Comparamos la concentración de tiramina y N-metilfenetilamina (NMP), 2 aminas fenólicas prominentes que pueden afectar negativamente la reproducción de los herbívoros, entre tallos maduros de guajillo y juveniles (rebrote) en áreas que habían sido aereadas y también entre tallos maduros en sitios aereados y sitios control. La aereación incrementó la concentración de NMP pero no la de tiramina de tallos maduros. Los tallos juveniles tuvieron una mayor concentración de $\mathbf{N}$ total que los tallos maduros, pero también tuvieron mayores concentraciones de amina hasta 1 año después de la aereación. Los tallos juveniles incorporaron un mayor porcentaje del nitrógeno total en aminas $(2.5-6.0 \%)$ que los tallos maduros (1.8-4.2\%). Las concentraciones de aminas alcanzaron sus máximos niveles en verano e inicios de otoño, un periodo en el que los herbívoros dependen grandemente del ramoneo porque las hierbas son escasas. Nuestros resultados sugieren que mientras la aereación puede resultar en mayores concentraciones de nitrógeno en el "Guajillo", el incremento en las aminas puede limitar los beneficios para los herbívoros.

nique) by producing large numbers of juvenile root sprouts which can have higher total leaf nitrogen content up to 6 months after treatment (3.7 for leaves from roller-chopped stems versus 2.4 $\mathrm{mg} \mathrm{N} / \mathrm{g}$ dry matter for leaves from untreated stems; Reynolds et al. 1992).

Phenolic amines are a class of nitrogen-containing, carbonbased secondary plant compounds that can occur in high concentrations in native shrubs of southern Texas and northern Mexico. When consumed at even low concentrations, phenolic amines can have severe physiological effects on domestic livestock, such as reduced reproductive performance (Forbes et al. 1993, 1994, Vera-Avila et al. 1996, 1997). Forbes et al. (1995) found that tyramine and N-methyl-phenethylamine (NMP) concentrations significantly increased in regrowth guajillo after simulated 
browsing. They warned that part of the increase in total nitrogen often observed in severely browsed or mechanically treated plants may be a result of increased nonprotein nitrogen such as phenolic amines.

We tested the hypotheses that: 1) amine concentrations of leaves from mature guajillo stems should be higher after aeration, and 2) leaves from juvenile guajillo stems, resprouting after aeration, should have higher concentrations of tyramine and NMP than leaves from mature plants.

\section{Methods and Materials}

\section{Study Area}

The study was conducted on the 10,000 ha Campo Santa Maria Management Area $\left(26^{\circ} 55^{\prime}, 100^{\circ} 40^{\prime}\right)$ located on the border of Nuevo Leon and Coahuila, Mexico, about $160 \mathrm{~km}$ southwest of Laredo, Tex.. The Pajaros Azules mountains (1,700 m above sea level) border the southern and western boundaries of the ranch and drop sharply to the plains ( $400 \mathrm{~m}$ above sea level) that compose the majority of the ranch holdings. Climate is characterized by hot, dry summers and cool, mild winters. Average annual rainfall in Progresso, Coahuila (40 km from study site) is 383 $\mathrm{mm}$ with peaks in May and September (Secretary of Agricultural Promotion of Coahuila 1997). Rainfall during the sampling period was $50 \%$ greater than the annual average.

The study was conducted in the La Mesa, La Mona, and Tinajas pastures which were dominated by guajillo and blackbrush (A. rigidula Benth.). Soils in La Mesa pasture were shallow sandy loams. Other common shrubs in this pasture included whitebrush (Aloysia gratissima Gill. \& Hook.), cenizo (Leucophyllum frutescens Berl.), guayacan (Guaiacum angustifolia Engelm.), and mesquite (Prosopis glandulosa Torr.). Soils in La Mona pasture included shallow sandy loams and moderately deep clay loams. Other common shrubs were cenizo, panalero (Schaefferia cuneifolia Gray), guayacan, whitebrush, and coyotillo (Karwinskia humboldtiana R. \& S.). Soils in Tinajas pasture were characterized by shallow sandy and gravelly loams. Other shrubs included cenizo, oreganillo (Lippia graveolens H.B.K.), Texas kidneywood (Eysenhardtia texana Scheele), and coyotillo. La Mona and La Mesa pastures were deferred from livestock grazing from October 1996 to September 1997, heavily grazed by cattle from mid-September 1997 to mid-November 1997, then not grazed for the rest of the study. Cattle were excluded from Tinajas pasture from October 1996 through the end of the study.

\section{Methods}

In late September-early October 1996, one, 30-ha site in each of the 3 pastures was aerated with 1 pass using a dual-drum Lawson aerator pulled by a crawler tractor. Sites were chopped in 100-120 m wide strips separated by $10-15 \mathrm{~m}$ of untreated vegetation. A control site (30 ha) of similar vegetation and soil types was demarcated in each pasture, adjacent to treated sites.

Beginning in December 1996 and continuing monthly through January 1998, 5 mature guajillo shrubs were randomly selected in each treatment by pasture combination and 30-50 $\mathrm{g}$ fresh weight of current annual growth leaves were clipped from each shrub. Treated areas contained a sufficient number of intact mature stems after treatment (600 stems/ha; Windels 1999) for sample collection after leaves grew back on these stems. Every month from December 1996 until October 1997, 5 clusters of juvenile stump sprouts, as defined by Bryant et al. (1991b), were randomly selected in each of the 3 aerated areas and 30-50 g were clipped from each cluster. Leaf material was only collected from ungrazed stems. Juvenile sprouts were rare in control areas throughout the study period and in treated areas after October 1997 and were not collected. Samples were not collected in January 1997 because frost damaged most leaves in the treated areas. Juvenile plant samples from April defrosted before lyophilizing. Sufficient juvenile stems were not available in La Mona pasture in October for an adequate sample, therefore $n=2$ for juvenile stems in October. Leaves were stored in Whirl-paks and frozen within 2 hours of clipping. Subsamples of approximately equal weight were selected from each of the 5 samples in each age/treatment/pasture combination, pooled, lyophilized for 24 hours, and ground over a $1 \mathrm{~mm}$ screen in a cyclone mill.

Amine analyses were conducted at the Texas A\&M Agricultural Experiment Station in Uvalde, Texas following extraction and analysis procedures of Pemberton et al. (1993). Briefly, $1 \mathrm{~g}$ of ground material was added to $20 \mathrm{ml} 1 \%$ glacial acetic acid and extracted overnight on a rotary shaker followed by filtering through filter paper to remove solid plant tissue. The extract was passed through a single-use Polysorb MP-3 high sulfonated, C18 poly- styrene solid phase extraction tube, which had been conditioned with $2 \mathrm{ml}$ HPLCgrade methanol, $2 \mathrm{ml}$ deionized water, and $2 \mathrm{ml} 1 \%$ glacial acetic acid. Four milliliters of extract were passed through the tube and eluted with $2 \mathrm{ml} \mathrm{10 \%} \mathrm{ammonium}$ hydroxide in methanol, after washing most unwanted compounds from the tube with 2 $\mathrm{ml}$ deionized water followed by $2 \mathrm{ml} 50 \%$ methanol. The eluent was then acidified by addition of $1 \mathrm{ml} 10 \%$ glacial acetic acid, followed by $1 \mathrm{ml} 4 \%$ phosphoric acid. Amine standards $(125 \mu \mathrm{l} / \mathrm{ml})$ were prepared in $0.1 \%$ phosphoric acid and refrigerated until use. Tyramine (4-hydroxyphenethylamine) and NMP were obtained from Aldrich Chemical Co., Inc. (Milwaukee, Wisc.) and phenethylamine from Spectrum Chemical Mfg. Co. (Gardena, Calif.). Both standards and extracts were separated by HPLC at ambient temperature on Waters Radial-pak cartridge (Nova-pak, 4cm, C18). Chromatograms and spectra were recorded with a Waters 490E programmable multiwavelength detector coupled to Waters 820 Maxima software.

We calculated plant nitrogen incorporated in tyramine and NMP by multiplying the mass of each amine per gram of plant by the percent nitrogen in each amine, as determined from the amine's molecular formula (tyramine $\left(\mathrm{C}_{8} \mathrm{H}_{11} \mathrm{NO}\right)=137.18$ $\left.\mathrm{g} / \mathrm{mol} ; \mathrm{NMP}\left(\mathrm{C}_{9} \mathrm{H}_{13} \mathrm{~N}\right)=135.21 \mathrm{~g} / \mathrm{mol}\right)$. The percent of total plant nitrogen that was incorporated into tyramine+NMP was calculated by dividing nitrogen in amines by total nitrogen in the plant determined from macro kjeldahl analysis at Texas A\&M University-Kingsville.

\section{Statistical Analysis}

Differences in amine concentration of leaves from mature stems due to aeration were analyzed with analysis of variance in a randomized complete block design with treatment, month, and treatment*month interaction as main effects (PROC ANOVA, SAS Inst. 1996). Differences in amine concentrations of leaves from mature and juvenile stems in aerated areas were also tested with analysis of variance in a randomized complete block design with age, month, and age*month interaction as model variables (PROC GLM, SAS Inst. 1996). These tests were repeated for differences in total leaf nitrogen content and for percent of total leaf nitrogen incorporated into amines (tyramine+NMP). Post-hoc means separation tests were done using least squares means (SAS Inst. 1996). Results were considered significant at $\mathrm{P}<0.05$. 


\section{Results}

Aeration did not affect tyramine concentrations in leaves from mature stems $(\mathrm{P}=$ $0.790)$ but did affect NMP concentrations $(\mathrm{P}=0.010$; Table 1); NMP concentrations increased an average of $11 \%$ in mature stems from aerated areas compared to control, with the largest differences in June, July, and October 1997 (Fig. 1). Amine concentrations were different among months for tyramine and NMP in mature leaves from aerated and control areas $(\mathrm{P}<$ 0.001 for both amine types). The treatment*month interactions were not significant $(\mathrm{P}>0.05)$. Tyramine concentrations were low during December 1996, increased to moderate levels during summer, peaked in October 1997, and declined to low or moderate concentrations during the final 2 months of sampling. Concentrations of NMP peaked during September.

$\mathrm{N}$-methyl-phenethylamine concentrations averaged $55 \%$ higher in leaves from juvenile leaves compared to mature stems from aerated areas $(\mathrm{P}<0.001 ;$ Table 1$)$ and there was no significant age*month interaction. A significant age*month interaction was detected for tyramine $(\mathrm{P}<$ 0.001). Tyramine concentrations in juvenile stems were nearly double those in mature stems during December 1996, February 1997, and May-July 1997 (Fig. 1). Amine concentrations were different among months for tyramine and NMP in juvenile leaves $(\mathrm{P}<0.001$ for both amine types). Tyramine concentrations in juvenile leaves peaked in June and July while NMP concentrations were elevated JuneAugust and peaked in September (Fig. 1).

Total leaf nitrogen in mature stems showed a treatment*month interaction $(\mathrm{P}$ $=0.03$; Fig. 2). Nitrogen concentration differed between mature stems from control and treated plots only in March 1997. An age*month interaction $(\mathrm{P}<0.001)$ was observed for differences in total leaf nitrogen between juvenile and mature stems

Table 1. Tyramine, $N$-methyl-phenethylamine (NMP), and nitrogen content of juvenile $(N=8$ months) and mature ( $\mathrm{N}=13$ months) guajillo stems, averaged across months, from plots aerated in October 1996 and paired controls, Coahuila, Mexico.

\begin{tabular}{|c|c|c|c|c|c|c|}
\hline & \multicolumn{2}{|c|}{ Juvenile } & \multicolumn{2}{|c|}{ Mature-Aerated } & \multicolumn{2}{|c|}{ Mature-Control } \\
\hline & Mean & $\mathrm{SE}$ & Mean & $\mathrm{SE}$ & Mean & $\mathrm{SE}$ \\
\hline Tyramine (mg/g) & $5.18^{\top}$ & 0.67 & $2.82^{A}$ & 0.25 & $52.76^{A}$ & 0.26 \\
\hline $\mathrm{NMP}(\mathrm{mg} / \mathrm{g})$ & $7.80^{\mathrm{a}}$ & 80.7 & $5.58^{\mathrm{bA}}$ & 0.33 & $5.03^{\mathrm{B}}$ & 0.26 \\
\hline Nitrogen $(\mathrm{mg} / \mathrm{g})$ & $33.2^{1}$ & 1.7 & $29.6^{2}$ & 1.2 & 30.5 & 1.5 \\
\hline Nitrogen in Amines (\%) & $4.21^{1}$ & 0.55 & $2.98^{\mathrm{A}}$ & 0.20 & $2.70^{\mathrm{B}}$ & 0.16 \\
\hline
\end{tabular}

${ }^{1}$ An age*month interaction $(\mathrm{P}<0.05)$ was detected in the comparison between juvenile and mature stems among months for this variable. Juvenile stems generally had greater means than mature stems, but differences varied by month. See text and figures for details.

${ }^{2} \mathrm{~A}$ treatment*month interaction $(\mathrm{P}<0.05)$ was detected in the comparison between aerated and control stems among months for this variable. Control stems had greater nitrogen content only in March 1997.

Juvenile and Mature-Aerated means followed by a different lower case letter were different $(\mathrm{P}<0.05)$.

${ }^{\mathrm{AB}}$ Mature-Aerated and Mature-Control means followed by a different capital letter were different $(\mathrm{P}<0.05)$. sample (i.e. $\mathbf{N}=\mathbf{2}$ instead of 3 ). from aerated areas; leaves from juvenile stems had higher total $\mathrm{N}$ in December
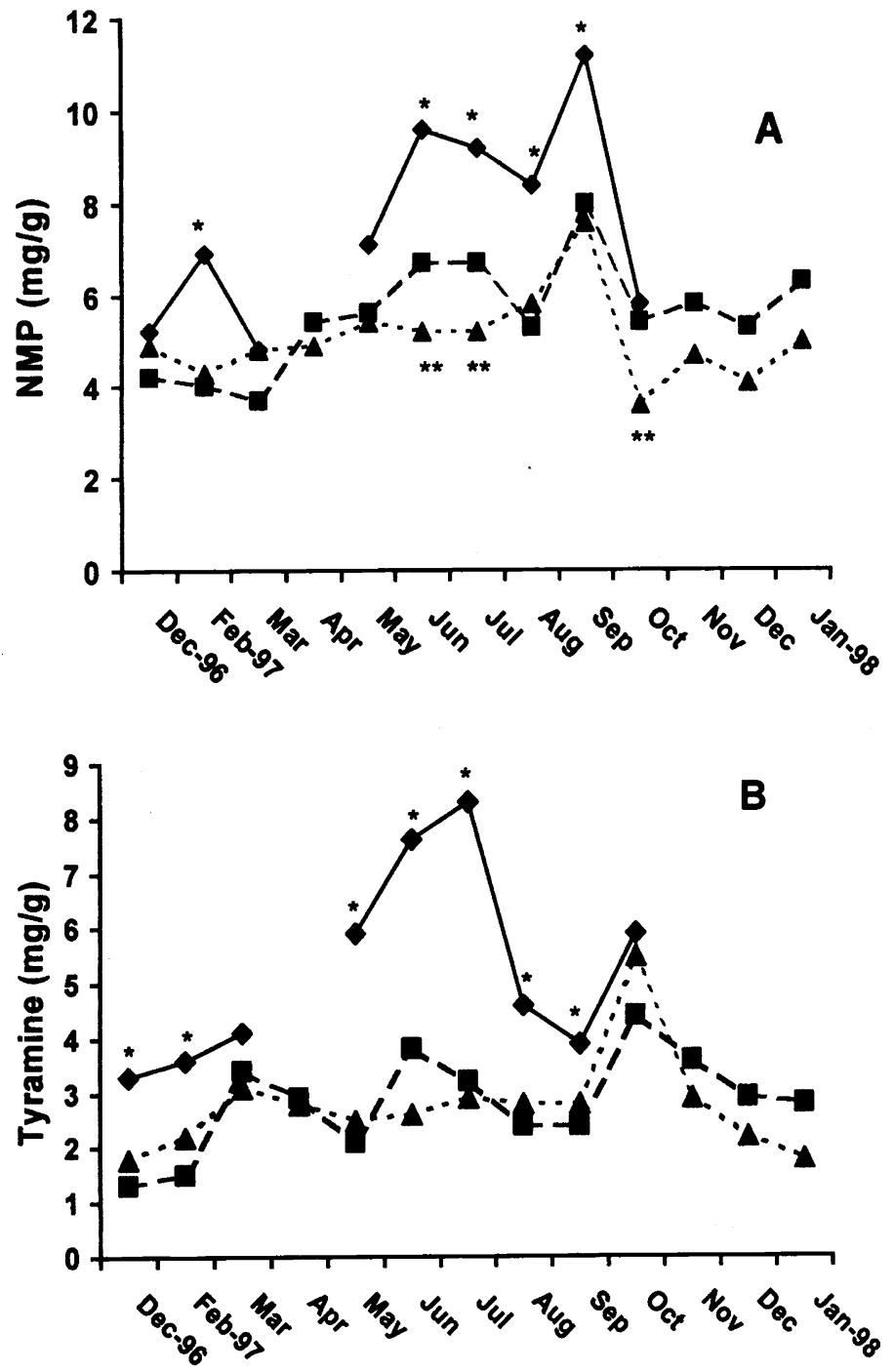

Fig. 1. Mean $(\mathrm{N}=3) \mathrm{N}$-methyl-phenethylamine (NMP; panel A) and tyramine (panel B) concentrations (mg/g) in leaves from mature and juvenile-phase stems collected from areas (n) 1996 and paired controls, Coahuila, Mexico. A “*” denotes months in denotes months in which mature stems in aerated plots differed from mature stems in control plots. Juvenile stem data in October were excluded from analysis because of a missing

1996 and February, May, and July 1997 (Fig. 2).

Percent total leaf nitrogen incorporated into amine (tyramine+NMP) nitrogen was 0.3 percentage points greater $(\mathrm{P}=0.04)$ in mature stems from aerated plots than from control plots (Table 1). No significant treatment*month interaction was observed. Amine nitrogen as a percent of total nitrogen peaked in summer for both juvenile and mature leaves in aerated plots (Fig. 2). The percent of nitrogen in amines was greater in juvenile stems than mature stems, although there was an age*month interaction $(\mathrm{P}=0.04)$. Juvenile stems differed from mature stems in MaySeptember (Fig. 2). 

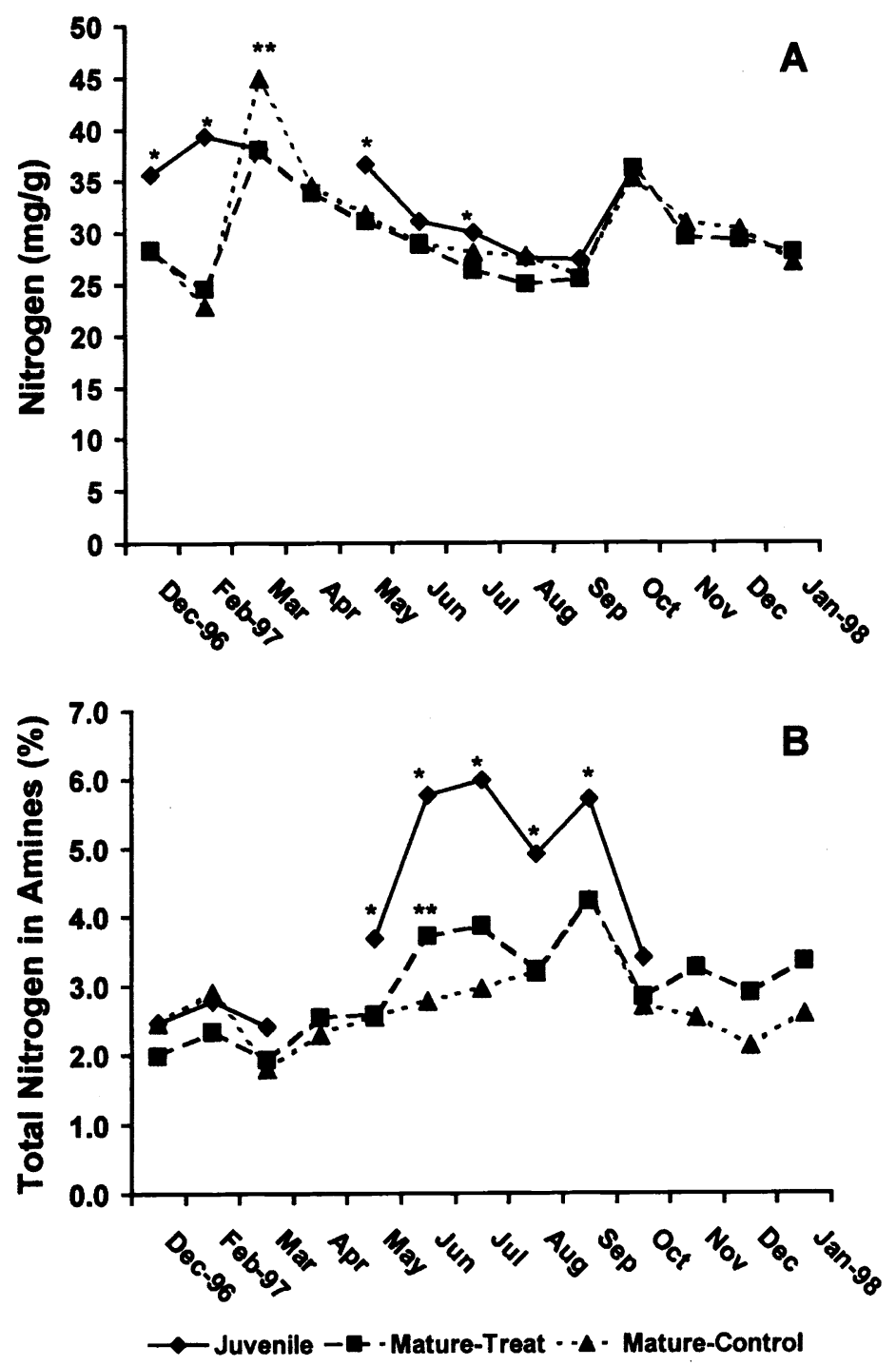

Fig. 2. Mean $(N=3$ ) nitrogen concentration (panel $A$ ) and percent of total nitrogen composed of amine nitrogen (panel $B$ ) in leaves from mature and juvenile-phase stems collected from areas aerated in October, 1996 and paired controls, Coahuila, Mexico. A “*” denotes months in which juvenile stems differed $(P<0.05)$ from mature stems in aerated plots and "**" denote months in which mature stems in aerated plots differed from mature stems in control plots. Juvenile stem data in October were excluded from analysis because of a missing sample (i.e. $N=2$ instead of 3).

\section{Discussion}

Reynolds et al. (1992) reported that total nitrogen in guajillo leaves could be temporarily increased during the nutritionally stressful times of late summer and early fall if roller-chopped in early July. Increased nitrogen concentration in guajillo leaves after aeration in our study was due primarily to growth of juvenile sprouts, which not only had higher nitrogen concentration but higher amine content compared to leaves on mature stems. The relative costs and benefits to an animal of mechanically treating guajillo will not be clear until nitrogen in mature and regrowth guajillo is fully characterized and more is known about the toxicity of guajillo's many secondary plant chemicals (Clement et al. 1997). However, range managers should be aware that mechanical treatment of guajillo is likely to increase concentration of amines, which in turn could negatively affect animal performance. Furthermore, it is unclear whether amine concentrations observed in juvenile stems in this study were affected more by plant age or seasonal climate and rainfall patterns, and therefore our results may not be applicable to guajillo treated in other seasons. If aeration can be timed such that early-stage juvenile sprouts with relatively lower amine:total nitrogen concentrations (i.e. juvenile sprouts in early spring of this study) are produced during the nutritionally stressful dry months, a valuable source of nitrogen can be provided while reducing intake of phenolic amines by wild and domestic herbivores. Further research is needed to investigate the effects of timing of aeration and rainfall on seasonal changes in amine and nitrogen concentrations in juvenile and mature-phase stems.

Forbes et al. (1995) demonstrated induction of chemical defense after simulated browsing by increased amine concentration in leaf regrowth from mature guajillo stems. Their study, however, did not investigate differences in amine concentrations between juvenile and adult-phase plants which is important in studying the effects of aeration because guajillo responds to top removal by producing multiple juvenile stems. Juvenility in plants is genetically controlled and phenotypically displayed in strong apical dominance (i.e. suppression of lateral branching and secondary growth) and low lignification (Kozlowski 1971, Bryant et al. 1991a). Juvenile plants of some species also display increased thorniness and variable leaf morphology (Kozlowski 1971). Severe browsing of juvenile plants can greatly reduce fitness by delaying reproduction. Therefore, juvenile stems of plants should be heavily defended (Bryant et al. 1983). Our observations of higher amine concentrations in leaves from juvenile stems than in leaves from mature stems support this hypothesis.

Nitrogen is often limiting for plants and therefore nitrogen-containing secondary compounds are expensive to produce, as they are ultimately derived from protein amino acids (Harbourne 1991). This is especially true in nitrogen-poor environments such as those found on our study site. During July-September, when total plant nitrogen was lowest and amines (tyramine + NMP) highest, nitrogen in tyramine and NMP was $4.9-6.0 \%$ of total leaf nitrogen in juvenile stems and 3.0$4.2 \%$ in mature stems (Table 2). More than 33 amines and alkaloids have been isolated from guajillo, with tyramine and NMP comprising $40-45 \%$ of total amine concentrations in spring and late fall (Clement et al. 1997). Therefore, though nitrogen incorporated into tyramine and NMP was only $2-6 \%$ of total nitrogen available, extrapolation to include nitrogen in other known nitrogen-containing plant secondary compounds suggests that 4$15 \%$ of total nitrogen is allocated to chem- 
ical defenses in the form of amines. Because guajillo does not have symbiotic associations allowing nitrogen-fixation (Forbes et al. 1995, Zitzer et al. 1996) and soil types in the study site are generally considered nutrient poor, the carbon/nutrient hypothesis predicts that guajillo's defenses should be carbon based instead of nitrogen based (Bryant et al. 1983). Dedication of large percentages of nitrogen in guajillo to chemical defenses seems to be an exception to the carbon/nutrient hypothesis, however, Jurena and Van Auken (1998) report nitrogen concentrations 5 times greater beneath guajillo canopies than in open areas, suggesting that nitrogen dynamics and the allocation of nutrients within woody plants in semiarid systems are not fully understood.

Tyramine and NMP concentrations in leaves from mature stems in treated areas did not differ from those in control areas 3 to 6 months post-treatment, suggesting any induction of defense in leaf regrowth from mature stems is not maintained. Forbes et al. (1995) showed significant increases in amine concentration up to 12 weeks after browsing but also concluded that induced defenses were not maintained. This short term induction may explain why we did not observe an increase in amine concentration in treated mature stems sampled 2 months after aeration. These observations and results from this study that amine concentrations varied between months support Forbes et al. (1995) conclusion that tyramine and NMP are 'dynamic' metabolites (Reichardt et al.1991).

Tyramine and NMP concentrations in mature leaves peaked in October and September, respectively, similar to a pattern described by Clement et al. (1997). Juvenile stems reached peak tyramine concentrations in July and peak NMP concentrations in September. Diet quality of ungulates during this period (July to September) is typically poor because low rainfall reduces biomass of forbs (Bozzo et al. 1992, Reynolds et al. 1992, Windels 1999). Wild and domestic ungulates rely heavily on browse from guajillo and blackbrush during dry summer and winter periods (Barnes et al. 1991, Martinez et al. 1997), and thus may be doubly stressed from low nutrient and high phenolic amine intake.

\section{Literature Cited}

Barnes, T.A., L.H. Blankenship, L.W. Varner, and J.F. Gallagher. 1991. Digestibility of guajillo for white-tailed deer. J. Range Manage. 44:606-610.

Bozzo, J. A., S. L. Beasom, and T.E. Fulbright. 1992. Vegetation responses to 2 brush management practices in south Texas. J. Range Manage. 45:170-175.

Bryant, J.P., F.S. Chapin, III, and D.R. Klein. 1983. Carbon/nutrient balance of boreal plants in relation to vertebrate herbivory. Oikos 40:357-368.

Bryant, J.P., P.J. Kuropat, P.B. Reichardt, and T.P. Clausen. 1991b. Controls over the allocation of resources by woody plants to chemical antiherbivore defense, p. 83-102. In: R.T. Palo and C.T. Robbins (eds.) Plant Defenses Against Mammalian Herbivory. CRC Press, Boca Raton, Fla.

Bryant, J.P., K. Danell, F.P. Provenza, P.B. Reichardt, and T.P. Clausen. 1991a. Effects of mammal browsing on the chemistry of deciduous woody plants, p. 135-153. In: D.W. Tellamy and M.J. Raup (eds.) Phytochemical Induction by Herbivores. Wiley, New York, N.Y.

Clement, B. A., C. M. Goff, and T. D. A. Forbes. 1997. Toxic amines and alkaloids from Acacia berlandieri. Phytochem. 46:249-254.

Forbes, T.D.A., B.B. Carpenter, R.D. Randel and D.R. Tolleson. 1994. Effects of phenolic monoamines on release of luteinizing hormone stimulated by gonadotropin-releasing hormone and on plasma adrenocorticotropic hormone, norepinephrine, and cortisol concentrations in wethers. J. Anim. Sci. 72:464-469.

Forbes, T.D.A., I.J. Pemberton, G.R. Smith, and C.M. Hensarling. 1995. Seasonal variation in two phenolic amines in Acacia berlandieri. J. Arid Environ. 30:403-415.

Forbes, T.D.A., D.R. Tolleson, C.M. Hensarling, and R.D. Randel. 1993. Effects of exogenous amines on reproduction in female angora goats. S. African J. Anim. Sci. 23:196-200

Harbourne, J.B. 1991. The chemical basis of plant defense, p. 45-60. In: R.T. Palo and C.T. Robbins (eds.) Plant Defenses Against Mammalian Herbivory. CRC Press, Boca Raton, Fla.

Holechek, J.L., R.D. Pieper, and C.H. Herbel. 1989. Range management: principles and practices. Regents/Prentice Hall, Englewood Cliffs, N. J.

Jurena, P.N. and O.W. Van Auken. 1998. Woody plant recruitment under canopies of two Acacias in a southwestern shrubland. Southwest. Natural. 43:195-203.
Kozlowski, T.T. 1971. Growth and development of trees, Volume I. Academic Press, New York, N. Y.

Martinez M., A., V. Molina, F. Gonzalez S., J.S. Marroquin, and J. Navar Ch. 1997. Observations of white-tailed deer and cattle diets in Mexico. J. Range Manage. 50:253-257.

Pemberton, I.J., G.R. Smith, T.D.A Forbes, and C.M. Hensarling. 1993. Technical note: an improved method for extraction and quantification of toxic phenethylamines from Acacia berlandieri. J. Anim. Sci. 71:467-470.

Reichardt, P.B., F.S. Chapin III, J.P. Bryant, B.R. Mattes, and T.P. Clausen. 1991. Carbon/nutrient balance as a predictor of plant defense in Alaskan balsam poplar: potential importance of metabolite turnover. Oecologia 88:401-406.

Reynolds, J.P., T.E. Fulbright, and S.L. Beasom. 1992. Mechanical rejuvenation to dampen seasonal variation in chemical composition of browse. J. Range Manage. 45:589-592.

SAS Inst. 1996. SAS/STAT ${ }^{\circledR}$ software: changes and enhancements through Release 6.11. SAS Inst., Inc. Cary, N.C.

Secretary of Agricultural Promotion of Coahuila. 1997. Meterological information of Coahuila (In Spanish). Office of the Secretary of Agricultural Promotion of Coahuila, Saltillo, Coahuila.

Vera-Avila, H.R., T.D.A. Forbes, and R.D. Randel. 1996. Plant phenolic amines: potential effects on sympathoadrenal meduallary, hypothalimic-pituitary adrenal, and hypothalamic-pituitary-gonadal function in ruminants. Domest. Anim. Endocrin. 13:285-296.

Vera-Avila, H.R., T.D.A. Forbes, J.G. Berardinelli, and R.D. Randel. 1997. Effect of dietary phenolic amines on testicular function and luteneizing hormone secrection in male Angora goats. J. Anim. Sci. 75:1612-1620.

Windels, S.K. 1999. Effects of roller-chopping on white-tailed deer nutritional carrying capacity and habitat, and phenolic amine content of guajillo in northeastern Mexico. M. S. Thesis, Texas A\&M UniversityKingsville, Kingsville, Tex.

Zitzer, S.F., S. Archer, and T.W. Boutton. 1996. Spatial variability in symbiotic $\mathrm{N}_{2}$-fixation potential of woody plants in a subtropical savanna ecosystem. J. Appl. Ecol. $33: 1125-1136$. 